\title{
Vernacular poetry and the spiritual Franciscans of the Languedoc: the poems of Raimon de Cornet
}

Book or Report Section

Accepted Version

post-peer reviewed manuscript

Leglu, C. (2013) Vernacular poetry and the spiritual

Franciscans of the Languedoc: the poems of Raimon de Cornet. In: Roach, A. P. and Simpson, J. R. (eds.) Heresy and the Making of European Culture: Medieval and Modern Perspectives, edited by Andrew P. Roach andJ ames R. Simpson. Ashgate, Farnham, pp. 165-184. ISBN 9781472411815 Available at http://centaur.reading.ac.uk/26072/

It is advisable to refer to the publisher's version if you intend to cite from the work. See Guidance on citing.

Publisher: Ashgate

Publisher statement: Details of the definitive version are available at http://www.ashgate.com/isbn/9781472411815 
All outputs in CentAUR are protected by Intellectual Property Rights law,

including copyright law. Copyright and IPR is retained by the creators or other copyright holders. Terms and conditions for use of this material are defined in the End User Agreement.

\section{www.reading.ac.uk/centaur}

\section{CentAUR}

Central Archive at the University of Reading

Reading's research outputs online 


\section{Vernacular Poetry and the Spiritual Franciscans of the Languedoc: the}

\section{Poems of Raimon de Cornet ${ }^{1}$}

Nos sumus joculatores Domini, et pro iis volumus in hoc remunerari a vobis, videlicet ut stetis in vera paenitentia. $^{2}$

[We are minstrels of the Lord, and this is what we want as payment: that you live in true penance.]

The Languedoc fostered a distinctive movement within the first and third orders of the Friars Minor, who broke away from the mainstream Franciscan community not only over the poverty controversy, but also through their cult of the apocalyptic and other writings of Petrus Johannis Olivi. Inquisition and other historiographical records are the main sources for the ideas of the adherents of the Languedoc's Spiritual Franciscans and Beguins between the papal bull Exiit qui seminat of 1279, and their virtual disappearance in the mid-fourteenth century. A number of major studies, most recently by David Burr, Sylvain Piron and Louisa Burnham, have considerably developed knowledge of this movement. ${ }^{3}$ In addition to this rich

\footnotetext{
${ }^{1}$ This paper was revised in the light of my participation in the Leeds IMC, and in the workshop 'La fi dels trobadors? L'espai occitanocatalà als segles XIII I XIV: velles preguntes i noves interpretacions', at the University of Girona, 25-26 November 2010, organised by Miriam Cabré and Sadurni Martí. My grateful thanks to them, as well as to Marina Navàs, Louisa Burnham, Georges Passerat and Gilda Caïti-Russo for their comments and suggestions. I was able to complete work on this article thanks to a research project grant from the Leverhulme Trust.

${ }^{2}$ Peter Loewen, 'Francis the Musician and the Mission of the Joculatores Domini in the Medieval German Lands', Franciscan Studies, 60 (2002): 251-90 (p. 259, from Speculum Perfectionis, chapter $8, \S 100,1.18)$.

${ }^{3}$ David Burr, The Spiritual Franciscans: From Protest to Persecution in the Century after Saint Francis (University Park, PA: Penn State University Press, 2003), pp. 248-54; Louisa A. Burnham,
} 
source material, there is the corpus of poems left by Frayre Raimon de Cornet, a poet of the Toulouse school of troubadour poetry (active between c.1323 and c.1341), who lived for a while as a Spiritual Franciscan. While Raimon’s surviving works are diverse, occasionally bawdy and touch on secular politics of his day, some of his poems have attracted attention because they depict him as someone who was implicated directly in the controversy. His vernacular poetry also sheds further light on the context for the Occitan translations of Olivi's works that survive in Italy. Raimon’s love poems have been interpreted as ambiguous adaptations of the writings of Olivi by Maurizio Perugi and Jordi Passerat. ${ }^{4}$ This chapter focuses on political-satirical poems that are less open to interpretation.

So Great a Light, So Great a Smoke: The Beguin Heretics of Languedoc (Ithaca and London: Cornell University Press, 2008); Sylvain Piron, ‘La Critique de l’Église chez les Spirituels languedociens’, in L’Anticléricalisme en France méridionale, Cahiers de Fanjeaux, 38 (2003): 77-109. Alan Friedlander, The Hammer of the Inquisitors: Brother Bernard Délicieux and the Struggle against the Inquisition in Fourteenth-century France (Leiden: Brill, 2000).

${ }^{4}$ Maurizio Perugi, Trovatori a Valchiusa: Un frammento della cultura provenzale del Petrarca (Padua: Antenore, 1985), pp. 70-160; Georges (Jordi) Passerat, ‘Le Joy Spirituel de Raimon de Cornet', in Le Moyen Age dans les Pyrénées catalanes, ed. Michel Zimmermann, Études Roussillonaises, 21 (2005): 127-35; also by Passerat, 'L’Église et la poésie: les débuts du Consistori del Gay Saber’, Cahiers de Fanjeaux, 35 (2000): 443-73, and ‘Les Outrances verbales d’un troubadour: le cas du spirituel toulousain Raimon de Cornet', in L'Anticléricalisme en France méridionale (milieu XIIe-début XIVe siècle), Cahiers de Fanjeaux, 38 (2003): 135-58. Sergio Vatteroni, 'La Version occitane de l’Exercens attribué à Pierre Jean Olivi (Assise, Biblioteca storicofrancescana di Chiesa Nuova, ms. 9)', in Études de langue et de littérature médiévales offertes à Peter T. Ricketts à l'occasion de son 70ème anniversaire, ed. Dominique Billy and Ann Buckley (Turnhout: Brepols, 2005), pp. 187-96. 
Poetry in the vernacular could be a double-edged weapon, as the mendicant orders knew well. The weaver Peire Esperendiu confessed to the inquisitor that when he witnessed the burning at the stake of two Beguins in the cemetery of Saint-Félix in Narbonne, he had been inspired by the ambivalent sermon that the abjured priest Bernard Maury had preached. ${ }^{5}$ Esperendiu would be sentenced and burned as a Beguin in $1327 .{ }^{6}$ The simplest rhetoric could boomerang if the audience was disposed to side with the preacher's victim, especially in a region that had long been well disposed towards heretodox religious communities, and where the prosecutors of heresy had defined it for over a century in terms of anticlerical disobedience. Furthermore, the Spirituals and Beguins were known to have and to hide books that were written in the vernacular, a phenomenon that has led Robert Lerner to state that 'the Beguins opened a new chapter in the history of the relationship between writing and resistance'. It is important, therefore, to treat literary texts as public documents that had a sensitive relationship with their intended audiences. ${ }^{7}$

Raimon de Cornet was a leading figure in the school of poetry cultivated within Toulouse’s Consistori de la sobregaya companhia del gay saber (hereafter, Consistory),

\footnotetext{
${ }^{5}$ Cited by James Given, ‘The Béguins in Bernard Gui’s Liber sententiarum', in Texts and the Repression of Medieval Heresy, ed. Caterina Bruschi and Peter Biller (Woodbridge and Rochester, NY: Boydell and Brewer and York Medieval Press, 2003), pp. 147-61, at p. 159, and by Burnham, So Great a Light, pp. 84-7.

${ }^{6}$ Louisa A. Burnham, 'A Prosopography of the Beguins and Spiritual Friars of Languedoc', Oliviana: Mouvements et dissidence spirituels, 2 (2006), item 236, <http://oliviana.revues.org/index37.html >
} [Checked April 10, 2013].

${ }^{7}$ Burnham, So Great a Light, pp. 24-30; Sergio Vatteroni, Falsa clercia: la poesia anticlericale dei trovatori (Alessandria: Edizioni dell’ Orso, 1999); Robert Lerner, 'Writing and Resistance among Beguins of Languedoc and Catalonia', in Heresy and Literacy, 1100-1500, ed. Peter Biller and Anne Hudson (Cambridge: Cambridge University Press, 1994), pp. 187-204, at p. 187. 
although he is not named among its seven founding members in their 'letter' of May 1323 that launched an annual poetry competition that would come to be known as the Jeux Floraux. ${ }^{8}$ The Consistory was a secular poetic circle like the informal groups that left traces in thirteenth-century Béziers and Marseilles, but with a devotional slant. Its earliest mantenedors ('upholders') straddled the diminishing divide between the episcopal Cité, once the seat of the counts of Toulouse, and the Bourg's university faculties and colleges, clustered around the Benedictine priory of La Daurade (a daughter house of Moissac) and the basilica of Saint-Sernin. Fourteenth-century Toulouse and its environs, despite having been part of the kingdom of France for a century, still looked towards the Crown of Aragon for trade and guidance. Overlapping powers coincided with the implantation of the Papacy first peripatetically in the region, and in Avignon after 1317, and the development of a curia that recruited heavily from Occitan-speaking regions. Linguistic protectionism emerged as a theme in Toulousain literary circles that were connected to the city's university, where many prominent Avignon figures had studied or taught. ${ }^{9}$

Although he was born in Saint-Antonin (Tarn-et-Garonne), and his father was a troubadour at the court of Count Henry II of Rodez, Raimon de Cornet had a strong connection with Toulouse. A lay citizen of Narbonne with the similar name Raimundus

\footnotetext{
${ }^{8}$ Las Leys d'Amors, ed. Joseph Anglade (4 vols, Barcelona: IEC, 1919-20), vol. 1, pp. 9-13; Catherine Léglu, Multilingualism and Mother Tongue in Medieval French, Occitan and Catalan Narratives (University Park PA: Penn State University Press, 2010), pp. 55-74; Laura Kendrick, ‘The Consistori del gay saber of Toulouse (1323-c.1484)', in The Reach of the Republic of Letters:
} Literary and Learned Societies in Late Medieval and Early Modern Europe, ed. Arjan van Dixhoorn and Susie Speakman Sutch (2 vols, Leiden: Brill, 2008), vol. 1, pp. 17-32; Douglas Kelly, 'The Late Medieval Art of Poetry: The Evidence from At de Mons and Raimon de Cornet', in Etudes de langue et de littérature médiévales offertes à Peter T. Ricketts (Turnhout: Brepols, 2005), pp. 681-92.

${ }^{9}$ See Philippe Wolff, Histoire de Toulouse, ed. Michel Labrousse, rev. edn (Toulouse: Privat, 1986). 
Corneti was active in 1313-14, implying that there was a family connection with the Languedoc-Roussillon. ${ }^{10}$ Our poet was awarded the first prize in the Jeux Floraux in 1333 for a Marian poem. Forty-four of his works are preserved in the Consistory archives in a compilation that is known as the Registre de Cornet (Toulouse, Bibliothèque municipale MS 2885), this codex in its current form comprising two damaged quaternions that were edited in 1888 by Noulet and Chabaneau as sections A and B of a single chansonnier. ${ }^{11}$ The Registre de Cornet echoes small-scale compilations that had been produced for some time in both Occitan and Catalan-speaking regions. ${ }^{12}$

Raimon also composed a treatise on Occitan grammar and versification, completed in September $1324 .{ }^{13}$ It survives within a harsh critique composed by the Consistory poet Joan

\footnotetext{
${ }^{10}$ Alphonse Blanc, Le Livre de comptes de Jacme Olivier: marchand narbonnais du XIVe siècle (2 vols, Paris: Picard, 1899), vol. 2, pp. 685-7, 696-7. A certain G. Cornet attested that he was a clerk in 1305, p. 544.

${ }^{11}$ The manuscript is online (see $<$ http://numerique.bibliotheque.toulouse.fr/cgibin/superlibrary?a=d\&d=/ark:/74899/B315556101_MS2885> [checked 10 April 2013]. Transferred from the archives of the Académie des Jeux Floraux in 2005. All references are to the edition by Jean-Baptiste Noulet and Camille Chabaneau, Deux manuscrits provençaux du XIVe siècle contenant des pièces de Raimon de Cornet, de Peire de Ladils et d'autres poètes de l'école toulousaine (Montpellier and Paris: Société pour l’Etude des Langues Romanes, 1888).

${ }^{12}$ See Valeria Bertolucci Pizzorusso, Morfologia del testo medievale (Bologna: Il Mulino, 1989), pp. 87-124, 125-46; Viçens Beltran, El cançoner de Joan Berenguer de Masdovelles (Montserrat: Publicacions de l'Abadia de Montserrat, 2006), pp. 13-22, 42-3, 72, and on troubadour compilations, pp. 50, 82, 95. Perugi, Trovatori a Valchiusa, p. 112.

${ }^{13}$ Joan de Castellnou, segle XIV, obres en prosa, ed. Josep M. Casas Homs (Barcelona: Fundació Salvador Vives Casajuana, 1969), ‘Glosari al Doctrinal de Ramon de Cornet’, pp. 161-203; citation from p. 161.
} 
de Castellnou in 1341 that is basically a defence of the 'rules' that had been established since. Both works are dedicated to Count Pere of Ribagorça and Ampuries, fourth son of King Jaume II of Aragon (1305-81). Pere is now remembered for his decision to enter the Franciscan order. ${ }^{14}$ Joan refers Pere to Raimon's versified 'letter’ to the Minister General of the Franciscan order, implying that this polemical work was known to him (Glosari, p. 168). He also says that Raimon was ‘ladoncs capella e ara monge blanch’ (a chaplain then [1324] and now a Cistercian [1341]), and that he had refused to rewrite his faulty early text on the grounds that it would be shameful to him (Glosari, p. 203). ${ }^{15}$ Nineteen of his poems were included in troubadour chansonniers produced in Catalonia (Biblioteca de Catalunya, MS. 146 and Biblioteca de Catalunya, MS. 7-8). ${ }^{16}$ However, internal evidence places Raimon

\footnotetext{
${ }^{14}$ Casas Homs, Joan de Castellnou, pp. 29-36; Martin Aurell, 'Messianisme royal de la Couronne d’Aragon', Annales: Histoire, Sciences Sociales, 52 (1997): 119-55 (p. 125); Amédée Pagès, 'Les Origines paternelles d’Auzías March, d'après de nouveaux documents', Bulletin Hispanique, 50
} (1948): 313-32 (p. 321).

${ }^{15}$ Pilar Olivella Madrid, 'Raimon de Cornet, una mostra de poesia tolosana a Catalunya', in Toulouse à la croisée des cultures: actes du Ve Congrès international de l'Association Internationale d'Études Occitanes, Toulouse, 19-24 août 1996, ed. Jacques Gourc and François Pic (2 vols, Pau: AIEO, 1998), vol. 1, pp. 167-77 (p. 177, n. 28). Lola Badia, Poesia catalana del segle XIV: edició i estudi del Cançoneret de Ripoll (Barcelona: Quaderns Crema, 1983), pp. 24-9.

${ }^{16}$ Pilar Olivella Madrid, ‘A propos de l’œuvre de Raimon de Cornet copiée en Catalogne’, in Colloque 'Jeunes Chercheurs en domaine occitan', Montpellier, avril 1998, in Bulletin de l'Association Internationale d'Études Occitanes, 14 (1998): 47-61. For editions, see Jaume Massó Torrents, 'Poésies en partie inédites de Raimon de Cornet et de Joan de Castellnou, d’après le manuscrit de Barcelone’, Annales du Midi, 26 (1914): 449-74 and 27 (1915): 5-36; Pilar Olivella Madrid, 'La poesia en llengua occitana durant la primera meitat del segle XIV: l'exemple de Raimon de Cornet' (unpublished doctoral dissertation, University of Barcelona, 2002). 
further north, under the patronage of Count John I of Armagnac, John's uncle Roger of Armagnac, bishop of Lavaur and archbishop of Auch, and their allies (A XXI, XXII, XXIII). Raimon addresses the Countess of Armagnac in the guise of a chaplain (see below). Court chaplains acted as priests, confessors and liturgical singers, but they could also be entrusted with the care of musical instruments and books. ${ }^{17}$ Raimon worked as an ordained chaplain until he joined the Cistercian order, possibly ultimately in the remote abbey of Pontaut (Landes), near Dax (B, IV). His Cistercian period was not the end of his poetic career, as one of his two surviving Latin poems is a sequence in honour of Bernard of Clairvaux (A XXXIII). ${ }^{18}$ He emulated the late-twelfth-century troubadours Bertran de Born and Folquet de Marseilles in this respect. ${ }^{19}$

Raimon de Cornet had another well-known model for his poetic persona, the Monk of Montaudon (active c.1193-1210). ${ }^{20}$ There is nothing heretical about Raimon's blend of biblical and secular material in lyric poetry, as the motet had achieved daring juxtapositions some 50 years earlier, but as a messacantan (Mass-singer) Raimon would have been aware of

${ }^{17}$ Dominique Barrois, 'Jean Ier, comte d'Armagnac, son action et son monde (1305-1373)' (unpublished doctoral dissertation, University of Lille-3, 2004), available online:

$<$ http://documents.univ-lille3.fr/files/pub/www/recherche/theses/barroisdominique/html/these_body.html> [checked 10 April 2013].

${ }^{18}$ St John E. Flynn, 'The Saint of the Womanly Body: Raimon de Cornet’s Fourteenth-Century Male Poetics', in Sex and Gender in Medieval and Renaissance Texts: The Latin Tradition, ed. Barbara K. Gold, Paul Allen Miller and Charles Platter (New York: SUNY Press, 1997), pp. 91-109.

${ }^{19}$ William D. Paden Jr, 'De monachis rithmos facientibus: Hélinant de Froidmont, Bertran de Born, and the Cistercian General Chapter of 1199', Speculum, 55 (1980): 669-85.

${ }^{20}$ Les Poésies du Moine de Montaudon, ed. Michael J. Routledge (Montpellier: AIEO, 1977). Marina Navàs, 'La figura literària del clergue en la poesia de Ramon de Cornet’, Mot so razo, 9 (2010): 7593. 
the condemnation in the papal bull Docta sanctorum patrum (1324/5) of polyphonic techniques in the divine office, and of the insertion of secular song in the vernacular within liturgical chant. ${ }^{21}$ The only rubric concerning music says that one debate poem should be sung to an existing melody. ${ }^{22}$ There is no sign that he practised anything but the monody that was traditional to both chaplains and troubadours, but he was active in a time and place that brought him into contact with new musical trends. ${ }^{23}$

Despite his conservatism, he seems to have remained an exponent of Spiritual Franciscan beliefs that cost several friars and Beguins their lives. Raimon's persona and words might have alluded to those fugitive friars who were able to continue preaching and delivering the sacraments by posing as secular priests through a network of Beguin 'safe houses' that was broken in the period 1325-28. The strongest evidence for this lies in his tensos (dialogue poems) and partimens (structured debate poems, often with an adjudicator). In his robust tenso with Raimon, Guilhem Alaman makes an explicit allegation:

E digatz me cum los frayres menors

Avetz layshatz, ni fag tan gran otratge,

Qu'auzit ay dir que, per lo beguinatge

Que faziatz ab fray Peyre Joan,

${ }^{21}$ Edward H. Roesner, 'Subtilitas et Delectatio: “Ne m’a pas oublié”', in Cultural Performances in Medieval France, ed. Roberta L. Krueger and others (Cambridge: Brewer, 2007), pp. 25-43; Daniel Leech-Wilkinson, ‘The Emergence of Ars nova', Journal of Musicology, 13 (1995): 285-317; Kevin N. Moll, 'Folio Format and Musical Organisation in the Liturgical Repertoire of the Ivrea and Apt Codices’, Early Music History, 23 (2004): 85-152 (pp. 140-143).

22 'E vay el so: “Aras can vey quel glas e la frejor”' ('It is sung to the melody "Now when I see that the frost and the cold ...”'), (A XLII, p. 86, fol. 39r).

${ }^{23}$ Carla Vivarelli, “"Di una pretesa scuola napoletana”: Sowing the Seeds of the Ars nova at the Court of Robert of Anjou', The Journal of Musicology, 24 (2007): 272-96 (pp. 288-91). 
Fos pres d'usclar az Avinho antan. (A XXX, ll. 14-18)

[And tell me how you left the Friars Minor, or caused such a great scandal, because I have heard that because of the 'Beguinizing' you were doing with brother Peter John, you came near to being burnt at Avignon, some time ago.]

Guilhem Alaman is referring to the events of 1317, when Pope John XXII and the new Minister General of the Franciscan order, Michael of Cesena, summoned 64 friars of the convents of Béziers and Narbonne to appear for questioning at Avignon. The two convents of Béziers and Narbonne had been awarded special status as havens for the Spirituals by Pope Clement V in 1312, and subsequently made themselves autonomous during the papal interregnum of $1314-16 .^{24}$ The Languedocian convents promoted a cult around the writings and the tomb of Petrus Johannis Olivi in the Franciscan church of Narbonne. In his lifetime, Olivi had described his work as an attempt to imbeguiniri ('beguinize') his listeners, and that neologism is at the root of Alaman's accusation, referring to the lifestyle of the Languedocian and Catalan Beguins, some of whom wore distinctive black or brown clothing, lived in a communal domus paupertatis (house of poverty) and gathered to listen to readings of Olivi's works. $^{25}$

At Avignon, 25 of the Spiritual friars were handed over as suspected heretics to the inquisitor of Marseilles, the Franciscan Michael Monachus (often translated as ‘Le Moine'),

\footnotetext{
${ }^{24}$ Petrus Johannis Olivi, De usu paupere: The 'Quaestio' and the 'Tractatus', ed. David Burr, Italian Medieval and Renaissance Studies, 4 (Florence and Perth: Olschki and University of Western Australia Press, 1992), pp. ix-xii. See also the accounts by Burr, Spiritual Franciscans, and Burnham, So Great a Light.

${ }^{25}$ Harold Lee, Marjorie Reeves and Giulio Silano, Western Mediterranean Prophecy: The School of Joachim of Fiore and the Fourteenth-century 'Breviloquium' (Toronto: PIMS, 1989), pp. 49-50.
} 
in November 1317. Of these, four refused to recant and were burned at the stake, also in Marseille. Those friars who had not been handed to the inquisition were dispersed, most were sent to remote Franciscan convents. Some were ordered to change their vows and to enter monastic orders. ${ }^{26}$ The idea that Raimon narrowly escaped the stake at Avignon chimes with the words of Angelo Clareno concerning the arrest of the dissident Franciscan Bernard Délicieux at Avignon in 1317. Clareno comments that his enemies spread a rumour that he was to be burned, like the four martyrs of Marseilles. ${ }^{27}$

Much has been made of the date of the tenso. Noulet and Chabaneau interpreted the word antan strictly as 'last year', and assumed that it referred to a trial and burning at Avignon in 1326. In fact, although antan may refer to 'last year' it usually means 'some time ago' ${ }^{28}$ A single Spiritual was tried and burned in Avignon on 19 November 1326. He was a priest from Narbonne named Bernard Maury who had had close dealings with the fugitive Peyre Trencavel. ${ }^{29}$ Olivi's writings on the Apocalypse were formally condemned in 1326 , although their prophetic interpretation by Franciscans had been persecuted for over a

${ }^{26}$ Burr, Spiritual Franciscans, pp. 168-77, pp. 191-206, pp. 212-37; Burnham, So Great a Light, pp. 42-50; Sylvain Piron, 'Michael Monachus, Inquisitoris sententia contra combustos in Massilia', Oliviana, 2 (2006), <http://oliviana.revues.org/index33.html> [checked 10 April 2013]. 27 ‘... hinc inde per Avinionem disseminabant, quod sicut in Marsilia illi quatuor fratres, ita et iste post paucos dies combureretur', quoted by Alan Friedlander, 'Processus Bernardi Delitiosi: The Trial of Fr. Bernard Délicieux, 3 September-8 December 1319’, Transactions of the American Philosophical Society, new series, 86 (1996): 1-393 (p. 52, n. 12). Jean-Louis Biget, ‘Autour de Bernard Délicieux: franciscanisme et société en Languedoc entre 1295 et 1330', Revue d'histoire de l’Église de France, 70:184 (1984): 75-93.

${ }^{28}$ Out of 56 examples listed in Peter Ricketts, Concordance de l'occitan médiéval: COM 2 (Turnhout: Brepols, 2005), none refer clearly to 'last year'.

${ }^{29}$ Burnham, 'A Prosopography', item 66. 
decade. ${ }^{30}$ Maurizio Perugi also accepts that antan refers to 'last year’ but he prefers to assign the poem to a date nearer $1318 .{ }^{31}$ It seems difficult to suppose that the 'ordained chaplain' who composed the Doctrinal in September 1324 could also be a friar who narrowly escaped the pyre in 1325-26. Unless, of course, Raimon were both a Spiritual Franciscan and a chaplain during those years. Perugi suggests that his reference to his wearing of the Franciscan habit for eight months and nine days in his satirical letter to Guiral Ot represents a short hiatus during Raimon's career as a chaplain, and therefore must imply a longer period as a Beguin. ${ }^{32}$ It seems simpler to suggest that Raimon never considered himself to have left the Franciscan order at all.

Guilhem d'Alaman was identified by Noulet and Chabaneau as the seigneur of Villeneuve-sur-Vère (Tarn) near Albi, but the Alaman were a large family. Intriguingly, a certain Guilhem Alaman was a parator (fuller) in Narbonne in 1313, as was the layman of that city called R. Cornet. This detail has the advantage of bringing the tenso into its immediate context, with the corollary that cloth-workers were prominent in Beguin communities. $^{33}$

Guilhem Alaman does not offer much of an idea of what Raimon was supposed to have believed. A tenso between the Gascon lawyer and poet Pey de Ladils and 'frayre Raimon de Cornet, monge' allows Raimon 'the monk' to express his disapproval of the wealthy and his preference for humble poverty. Poverty was a crucial component of what Burr calls

\footnotetext{
${ }^{30}$ Burr, Spiritual Franciscans, p. 232.

${ }^{31}$ Perugi, Trovatori a Valchiusa, pp. 96-8, 104-5.

${ }^{32}$ Ibid., pp. 106-7, 112-4.

${ }^{33}$ Deux manuscrits, pp. xv-xvi. See Un Cartulaire et divers actes des Alaman, des de Lautrec et des Lévis, ed. Edmond Cabié and L. Mazens (Toulouse: Chauvin et fils, 1882); Blanc, Le Livre de comptes, pp. 698-9, 756.
} 
Franciscan self-understanding, and it distinguished the Friars Minor from other mendicant orders, but it had no implicit polemical significance by this time as long as it did not stray into the usus pauper controversy. Usus pauper, the 'poor' (restricted) use of goods without excess or stockpiling, was a crucial definition of Franciscan rigorism and the disputes concerning it after 1279 turned not on its importance but on whether or not it was included in the order's vows. ${ }^{34}$ In the ninth stanza, Pey turns his attention to Raimon's personal situation: Mossen Raimons, yeus vi frayre menor, Cortes e bo, certas, per quem desplatz Quar monge blanc rustix vos etz tornatz, Escas e prim, vila, dreyt laurador, E si l'abatz vostres fos coratjos Queus des pro carn tot jorn e del vi blos, Ja d'aquel loc pueus nous vira partir, Ayssi cum faytz, Dieus vonh layshe gauzir! (A XLII, 1l. 65-72) [Sir Raimon, I saw you when you were a courtly, good Friar Minor, for sure, which is why it displeases me that you have turned into a rustic white monk: tight-fisted and adroit, a peasant, a true ploughboy, and if that abbot of yours was sincere, giving you good meat and good wine every day, then you would never leave this pious place, as you are doing, at God's pleasure!]

\footnotetext{
${ }^{34}$ Burr, Spiritual Franciscans, pp. 43-65, 89-90, 118-28, 137-50. Kevin Madigan, Olivi and the Interpretation of Matthew in the High Middle Ages (Notre Dame, IN: University of Notre Dame, 2003), pp. 64-6.
} 
Raimon replies in kind to the 'nessis avocatz' ('stupid lawyer'): 'Li monge blanc son de granda labor/ E valo may quel mendican, sabchatz' (ll. 73-4) ('the Cistercians work very hard and they are worth more than the mendicants, you know'). But are Raimon's new brothers worth more than the friars in material rather than moral terms? Raimon retains his stated preference for a simple life but refuses to be drawn on why he has entered the Cistercian order. ${ }^{35}$

Raimon defends poverty in other poems as a moral and an intellectual principle: 'Noone should marvel at a man of fine intelligence (ome suptil) when poverty holds him lightly in its bonds, because gain has never been a sign of keen intellect (suptilitatz)' (A XXI, ll. 13). Suptilitas, the ability to perceive and to deploy fine points of detail is associated with poverty, a less-than-obvious association to make at a time when the theorist Johannes de Grocheio advised composers to restrict musical-poetic genres that involved subtilitates, such as the motet, strictly to audiences of the litterati. ${ }^{36}$ Joan de Castellnou seems to dismiss Raimon's intellectual efforts with a slighting neologism, the verb subtiliar: 'Per clausamen parlar se cuia l'actors aysii a subtiliar' (By speaking obscurely the author imagines that in this way he is being subtle) (Glosari, p. 171). Olivella Madrid has argued that Raimon's revival of obscure or clus composition in troubadour poetry is more a literary than an ideological gesture, but Joan is clearly distinguishing between Raimon’s clus poetry ('clausamen parlar’)

\footnotetext{
${ }^{35}$ Deux manuscrits, p. 86.

${ }^{36}$ See Perugi, Trovatori a Valchiusa, pp. 135-6; Roesner, p. 40; Gerald R. Hoekstra, ‘The French Motet as Trope: Multiple Levels of Meaning in “Quant florist la violete/El mois de mai/Et gaudebit”', Speculum, 73 (1998): 32-57 (pp. 49-52), and Christopher Page, Discarding Images: Reflections on Music and Culture in Medieval France (Oxford: Clarendon, 1993), pp. 65-111.
} 
and his quest for subtilitas. ${ }^{37}$ Subtilitas was used by the founders of the Consistory to define their learned membership as 'subtils trobadors', but the Consistory had devotional ambitions. One poem describing the power of God asserts that the divine essers (being) is so 'Excellens, nautz e tan passans/que per subtilitat de cor/Hom no y atenh per degun for' (excellent, high and powerful that no man could attain even its outskirts through the subtlety of his heart). ${ }^{38}$ Raimon's definition of poverty as the prerogative of an elite is dedicated to 'lo mieus senhor de Lombers', possibly Gui of Comminges, although the title was disputed at the time. ${ }^{39}$ He defends ‘subtle’ poverty again in a partimen with a certain Guilhem Gras, who orders him to choose between ‘esser bos ab manentia/O paubres humils veray’ (A XXXI, ll. 3-4) ('being good with wealth, or truly poor and humble'). Gras requests an answer according to the spirit rather than the letter of the law, 'justal sen de la letreta', (l. 6) because the question is neta ('clear', or 'pure’). Raimon's response is clear enough, for he cites the bruneta, the brown garb of the Beguin:

$$
\begin{aligned}
& \text { Senh-en W., nueyt e dia } \\
& \text { Paubretatz ab mi s’estay, } \\
& \text { E ja lun temps, on que sia, } \\
& \text { De paubretat nom partray, } \\
& \text { Car Jezu Crist, cert o say, }
\end{aligned}
$$

\footnotetext{
${ }^{37}$ Pilar Olivella Madrid, 'A propòsit de l'obscuritat en la poesia amorosa trobadoresca del segle XIV', in Convivio: Estudios sobre la poesía de cancionero, ed. Vicenç Beltrán and Juan Paredes (Granada: Editorial Universidad de Granada, 2006), pp. 585-609.

${ }^{38}$ Leys d'Amors, vol. 1, p. 21, ll. 1-2.

${ }^{39}$ Deux manuscrits, p. xxxiii. Eugène Martin-Chabot, 'Contribution à l'histoire de la famille Colonna de Rome dans ses rapports avec la France', Extrait de l'Annuaire-bulletin de la Société de l'histoire de France (Paris: Daupeley-Gouverneur, 1921), pp. 24-5, 35.
} 
Pres paubriera mot basseta,

E pogra vestir bruneta,

Mas sofraytos

Layshet l'aver perilhos. (A XXXI, ll. 11-20)

[Sir Guilhem, Poverty stays with me night and day, and for a long time now, wherever I might be, I have not parted from Poverty. Because I know for sure that Jesus Christ took on the lowest poverty and he could have worn the brown habit, but he suffered to set aside dangerous wealth.]

Paubretat is indissociable from the courtly virtues and vices that had long populated troubadour poetry, such as Pretz (Worth) or Malvestatz (Wickedness), and Perugi suggests that Raimon chose to echo the poems of the twelfth-century moralist Marcabru. ${ }^{40}$ Raimon therefore distinguishes poverty as experience (paubriera) from a personified companion, Poverty (Paubretat). ${ }^{41}$ Gras warns Raimon that his espousal of Poverty will earn him hunger and unnecessary suffering while a rich man can save his soul through good works. Raimon answers:

Fam e set e portar chiera

Fan venir a salvamen;

Penedensa dreyturiera

Torna pecatz a nien;

Riquezas Dieus nos defen,

De paubretat fay doctrina,

Car es de mals medecina; (ll. 31-7)

\footnotetext{
${ }^{40}$ Perugi, Trovatori a Valchiusa, p. 108.

${ }^{41}$ Lee, Reeves and Silano, Western Mediterranean Prophecy, p. 49.
} 
[Hunger, thirst and wearing a hair shirt bring one to salvation; true penance turns sins to nothing. God forbids us amassing wealth; I make a doctrine of Poverty, because it is a medicine against evil.]

Guilhem praises again the beauty and generosity of the rich man, but he adds 'Car, ses usclar,/Del gran foc me say gardar’ (ll. 49-50) ('because, without being roasted, I can save myself from the great fire'). Raimon ignores his allusion to the risk of either hellfire or execution and states: 'Paubretat mot sotileta/Vuelh tener ab cor joyos’ (ll. 51-2) ('I wish to maintain the most intelligent poverty with a joyful heart'). His point is clear: the poverty of suptilitas is that of the Beguin and the Spiritual friar who is risking his own life in remaining loyal to it. As it is a structured poetic debate, Guilhem Gras appoints two judges who will adjudicate on their disputation, ‘senh’en W. de Fontanas’ and ‘sen Johan de Fontanas’ (ll. 61-70), prominent men in civic government in Toulouse. En Guilhem ('W.') de Fontanas reports that he has shown the partimen to learned clerics who conclude that Poverty is 'cocelhs,/Clars cum espelhs,/Es de Dieu’ (jutjamen, ll. 8-10) ('It is advice, as clear as a mirror, from God'). In the 'other judgement', Johan de Fontanes rules that the rich man is worth more than the pauper. Poverty may be recommended by God, but, he seems to conclude, the rich man's lot is preferable (l'autre jutjamen, ll. 9-10).

Raimon's defense of evangelical poverty does not distinguish between unobjectionable mendicancy and usus pauper. ${ }^{42}$ By raising the issue at all, the partimen invites its participants and audience to consider poverty as a spiritual and temporal ideal that is failed by both the clergy and the laity. Raimon does not come across as a rigorist in this poem, but he does align himself by implication with the Spirituals and the Beguins. It is worth noting that in other

\footnotetext{
${ }^{42}$ Burr, Spiritual Franciscans, pp. 262-77.
} 
contexts, Raimon seems to be critical of the brown-clad mendicants' antagonistic attitude towards the rich men who support them. ${ }^{43}$

A further partimen opens with an invitation by Arnaut Alaman, a domicellus of Albi, to Raimon to display his suptilitas, his ‘suptil entendemen’, in discussing if he would prefer to be in Heaven but disliked by God, or in Hell and earning divine approval (A XXXII, l. 2). Raimon unpicks his absurd proposition, and Alaman accuses him of preaching heretical doctrine (ll. 21-2; 1l. 51-2). Without appealing to an adjudicator, Raimon closes the debate with a traditional envoi or tornada that references papal authority:

Amix n’Arnautz, sil sans payres volia

Qu'ieu fos rectors, yeu say que regiria

Totas mas gens que no seriu errans

Ni ja d'ifern, coma vos, espectans. (ll. 53-6)

[Arnaut my friend, if the Holy Father wished me to become a rector, I know that I would advise all my charges not to be in error and not to be expecting Hell, like you.]

The tornada leaves a question mark over Raimon's status. Is he in a position to be reassigned to a particular position by the Pope? Guilhem Alaman waxes ironic about his status as a secular priest who can sing mass and hear confession: 'Ramon Cornet, car etz messacantan,/Vos diray tost de mon afar cum es’ (A XXX, ll. 10-11) ('Raimon Cornet, as you are a mass-singer, I will tell you all about my situation'). He calls him 'glotz capelas, caytius, e mal apres’ (l. 29) ('a gluttonous chaplain, wretched and badly educated'), and harries him with the words:

\footnotetext{
${ }^{43}$ Passerat, 'Les Outrances verbales', pp. 139-42, offers an usus pauper reading of stanzas 17-18 of the Versa, but the translation is problematic and the passage may be critical of it, see his $\mathrm{n}$. 11 for the translation suggested by René Nelli.
} 
Ramon Cornet, per capela salvatge

Vos teno selh que sabo vostr'uzatge,

Que tavernas anatz tot jorn sercan,

E las nossas nous van ges oblidan. (A XXX, ll. 59-62)

[Raimon Cornet, people who know your behaviour think of you as a feral chaplain, because you go looking for taverns all day long, and you have not yet forgotten those wedding celebrations.]

If people think of Raimon as a capela salvatge, his frequentation of 'taverns' might be viewed as evidence that he still seeks out communal gatherings of the laity. The noun nossas is almost always applied to wedding celebrations in Occitan poetry, and appears once in the context of a spiritual marriage, in a hagiography composed around the year $1300 .^{44}$

The best comparative source for the Beguin context for Raimon de Cornet is the career that has been reconstructed by David Burr from a confession that was made in 1325 by Raymundus Johannis, who had been a Spiritual friar in the convent at Narbonne some time before the year 1300. He promoted the cult of Olivi at Narbonne, but he also worked as a confessor and priest in other regions. He was called to Avignon in April 1317 and was eventually placed in the custody of a remote convent at Anduze, which he fled. He spent some nine years in Gascony as a fugitive, often posing as a secular priest, notably in the town of Montréal (Gers). He was captured in 1325 and handed over to an inquisitorial tribunal at Carcassonne. His confession was included in the sentence that proclaimed his abjuration of

\footnotetext{
${ }^{44}$ Peter Ricketts, COM 2, eight examples consulted. Raimon Feraud, La Vida de Sant Honorat, ed. Ingegard Süwe (Uppsala: A.-B. Lundequistka Bokhandeln, 1943), 1l. 9026-27. Compare the discussions by Perugi, Trovatori a Valchiusa, p. 96 and Passerat, 'Les Outrances verbales’, p. 146.
} 
his beliefs in $1328 .{ }^{45}$ He was condemned to perpetual imprisonment in chains, on bread and water, and stripped of ecclesiastical office. One Beguine (a niece of Olivi's) confessed to the inquisitor that she had provided six fugitive friars with secular clothing that they wore over their habits, in order to pose as secular priests. ${ }^{46}$ The friar who concealed his short brown habit under secular clothing was the living retort to the traditional accusation, present in another poem in the Registre de Cornet, that mendicants hid their debauchery under their religious habit (A II, ll. 66-78).

Some fugitive friars fled to Italy and others sought protection in Mallorca and Sicily. Raymundus Johannis is said to have travelled extensively and made at least one journey to Sicily, possibly in 1324, and another to Mallorca. ${ }^{47}$ It is clear from the diffusion of his poems that Raimon de Cornet made at least one extended visit to the Crown of Aragon. The difference between their ultimate fates set aside, there are striking resemblances between the ageing heresiarch of Montréal and the younger poet of Saint-Antonin. Raimon de Cornet could not have 'beguinized’ the laity with Olivi, who died in 1298, but Raimon de Cornet would have known Raymundus Johannis personally as early as 1317 if he was part of the group of Spirituals who were summoned to Avignon. Cornet's frequent references to his wearing the habit of the order are intriguing. He remarks to the countess of Armagnac in one canso:

Bem fora mielhs que mos vestirs fos brus,

Ayssi cum sol, o que fos dins un cros

Vius sebelhitz, si no puesc gracios

\footnotetext{
${ }^{45}$ David Burr, 'Raymond Déjean: Franciscan Renegade,' Franciscan Studies, 57 (1999): 57-78; Burr, Spiritual Franciscans, pp. 212-21.

${ }^{46}$ Burnham, So Great a Light, pp. 110-11; Burr, 'Raymond Déjean’.

${ }^{47}$ Burnham, So Great a Light, pp. 110-112.
} 
Esser a lies que tot jorn m'abelis,' (ll. 41-4)

[It would be better were I still garbed in brown, as I used to be, or buried alive in a hole, on bread and water, if I cannot be gracious towards she who grows more lovely to me every day.]

He adds that 'Certanamen, sitot soy capelas,/Ma Roza vol, que mielhs ol que sipres,/Quem done gaug' (For sure, as I am a chaplain, I want My Rose - who smells sweeter than cypress - to give me joy) (ll. 49-50). Were he still a Friar, were he a recluse (or a prisoner), he would not enjoy the freedom to pay homage to a noblewoman that is afforded a secular priest. His words play on the Song of Songs, as Raimon often does in his religious lyrics, to present a subtle critique of the carnal church, even as they appear to celebrate it. It must be stressed however that although Raimon’s love lyrics can be interpreted as Spiritual, the number of allusions that they contain to the writings of Bernard of Clairvaux (noted by Perugi who reads these texts as apocalyptic) would argue for their association with his Cistercian period, in other words, with the closing years of his career. ${ }^{48}$

As was said above, Raimon addressed a versified Letra to Guiral Ot (Geraldus Odonis, 1285-1349), a Parisian master of theology, elected Minister General of the Franciscan order in 1329, whose early career had included a teaching post in theology and logic in the Franciscan studium of Toulouse. ${ }^{49}$ Guiral Ot, like Pope John XXII and many of the prelates

\footnotetext{
${ }^{48}$ Perugi, Trovatori a Valchiusa, pp. 113, 120-126.

${ }^{49}$ Compare Passerat, 'Les Outrances verbales’, pp. 150-155; Francesco Costa, 'Geraldo Oddone, O. Min., Ministro Generale, Patriarca d’Antiocha e Vescovo di Catania (1342-48)', in Francescanesimo e cultura della Provincia di Catania: Atti del Convegno di studio, Catania, 21-22 dicembre 2007, ed. Nicoletta Grisanti (Palermo: Biblioteca Francescana, 2008), pp. 21-103 (p. 26). Editions and studies of Odonis's writings have flourished in recent years, and he is the object of a special issue of
} Vivarium, 47: 2-3 (2009); for a useful survey, see Costa, ‘Geraldo Oddone’, pp. 88-93. According to 
of the curia, originated from the Occitan-speaking Quercy. He is credited with composing hymns and liturgies, which makes him a credible recipient for a poem. ${ }^{50}$ The versified letter is internally dated 1330, so it was composed shortly after Guiral was elected Minister General (10 June 1329). Raimon opens with fulsome praise for Guiral’s temporal authority (italics mine):
Al bo relegios,
On gran devocios

Par a ssels que l'an vist,

Al bo senhor en Crist,

A frayre Guiralot,

Al prelat mot devot,

Ministre general

E senhor principal

De tot frayre menor,

Al mot descret senhor

En la divinitat,

On l'an amaestrat

Li bon clerc de Paris,

Al cenhor gent assis ... (A VI, ll. 1-14, my emphasis)

[To the good man of religion, in whom great piety is visible to all those who have seen him, to the good lord in Christ, to brother Guiral Ot, to the most devout prelate, minister general

Claude Trottmann, La Vision de Dieu aux multiples formes (Paris: Vrin, 2001), Odonis lectured on the 'Ten Signs of the Last Judgement', in Toulouse, p. 10 n. 3.

${ }^{50}$ Costa, ‘Geraldo Oddone’, p. 96. 
and principal lord of all the Friars Minor, to the most refined lord in divinity, who was taught his magisterial learning by the good clerks of Paris, to the well-established lord ...]

Should a Franciscan be called senhor? Should he exercise lordly status even in his learning? Raimon then introduces himself as 'frayre Raimon de Cornet' (ll. 18-19) and (in a damaged section) praises some men for preventing the growth of heresy, for without these physicians of the sinful soul, 'there would be a thousand times more heretics' (1. 28). The irony becomes sarcasm. These men are marvellous performers of Mass, anxious to earn the gifts that make them rich and proud (1l. 35-44). He reviews the mendicants' abandonment of humble clothing: 'Ges fort gran penedensa/Per lor abit no fan' (ll. 67-8) ('they do not perform great penitence through their habit'). A friar in their order would enjoy an abundant diet (ll. 93-6). His attack on the corruption of the clergy is not unusual in itself, but he seems to emphasise the hypocrisy of those friars who are also teachers and prelates:

Mas Dieu quel mon soste

Nos det aquest ishemple:

'Sels que veyretz el temple

Cezer en las cadieras

Cresetz, car vertadieras

Paraulas vos diran;

Mas jas o que faran

Vos autre no fassatz’. (1l. 115-22)

[But God who carries the world has given us this exemplum:

'Believe those whom you see seated on the chairs in the temple, because they will speak true words to you; but do not, you others, do as they do!'] 
Cornet criticises the mendicants: the Dominicans, Carmelites, Augustinian Friars and Franciscans (ll. 123-67). Later, he advises his reader (is it still Guiral Ot at this point?) ‘S’ab lor voletz parlar,/Trazetz lo capayro' (ll. 168-9) ('If you wish to speak to them, remove your hood') as they only want to speak to well-dressed men. The following passage is a key source for identifying Raimon as a former Spiritual, but it is damaged:

Car elh certamen crezo

May valer qu'autras gens,

Car porto vestimens

de faysso deguizada,

Laquals fo comensada

Per seguir la carriera

De veraya paubriera,

Que nos mostret Gesus (ll. 174-81)

[For they truly believe that they are worth more than other

people, because they clothe themselves with a disguised countenance, that which was started in order to follow the path of true poverty that Jesus showed us ...]

The whole of the side of the folio has been lost, corresponding to two columns of text, rectoverso, a gap of some 84 lines, (f. $10 \mathrm{r}-\mathrm{v}$ ). The tiny fragments that subsist of the missing sections that precede this biographical statement are tantalising. The 12th to 17th lines of the right-hand column (p. 17 of the bound manuscript) were not published but they can be transcribed thus:

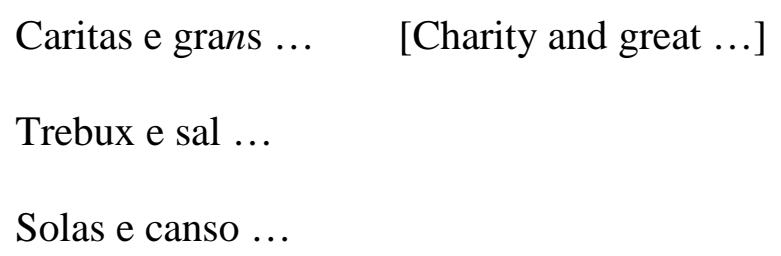


Porto quan $\mathrm{f}$... $\quad$ [They carry/wear when ...]

Alqu frayre [Some brother ...]

Mas pueus ...

Van pes nutz ... [They go barefoot ...]

Quus vuelha ...

Per girar viso ... $\quad$ [To turn the face away ...]

There are hints of Bernard Gui’s description of the activities of Beguins, who went barefoot and turned their heads towards the wall during Mass. ${ }^{51}$ The poem's conclusion shows that Raimon has just discussed the Spirituals crisis openly:

Car .viii. mes l'ay portat

E.ix. jorns per vertat,

Sufren grans vilanias

E motas parlarias

D’alqus frayres savays,

Per queus dic que jamays,

Senhers, no mi tendran,

Mas qu'a Dieu vos coman

Queus dona bona vida.

La pistola complida

Vos ay, per gran amor,

L'an de nostre senhor

.M. e .ccc. e .xxx.

La qual mos cors presenta,

De bon cor e d'umil,

${ }^{51}$ Burnham, So Great a Flame, p.35. 
A ma Roza d'abril

Gentil. (ll. 182-98)

[... because I wore it for eight months and nine days, truly, enduring appalling treatment and many vociferous exchanges with those wicked brothers, which is why I say to you that never, my lord, will they have me, unless I commend you to God, that he might give you a good life. I completed this letter for you, through great love, in the year of Our Lord 1330, which I present in person, good and humble in heart, to my noble Rose of April.]

Raimon complains about the mistreatment he had received from some fellow Franciscans during a period of less than nine months when he either wore a specific item of clothing, most probably the short habit adopted by the Spirituals. $N o[n]$ mi tendran is ambiguous, because the verb tener means both to have and to hold, the order will not 'hold' him unless he brings his letter to a respectful conclusion.

Although Guiral Ot was elected Minister General at the height of the poverty controversy, and would take harsh measures himself in 1331, one of his earliest works, written in Toulouse between 1315 and 1317, had been an enthusiastic response to a treatise on economics by Olivi. ${ }^{52}$ Raimon seems keen to appeal to Guiral Ot, but the matter of his poem consists of a denunciation of everything Guiral’s position as Minister General now represents. A Franciscan who is a senhor, who demands displays of epistolary and bodily grovelling, is not worth impressing. The Letra remains unsent, a gift to the Virgin. There is no evidence to support Perugi's suggestion that Raimon wrote the letter after he had become

\footnotetext{
${ }^{52}$ Giovanni Ceccarelli and Sylvain Piron, ‘Gerald Odonis’ Economics Treatise’, Vivarium, 47: 2-3 (2009): 164-204. Burr, Spiritual Franciscans, pp. 302-4.
} 
a Cistercian, but it articulates his rejection of the conventual Franciscans most eloquently. ${ }^{53}$ The fact that Joan de Castellnou referred to it in 1341 as a text that was known to Count Pere de Ribagorça shows that it had circulated widely (see above).

To understand the poem better, we have to return to Raymundus Johannis, some three years before the Letra. Two female deponents alleged that he explained his decision to leave the Friars Minor as the result of persecution:

Again, he said he did not consider himself to be excommunicated or irregular or apostate from his order because, as he said, he did not leave his order with the intention of apostatizing, transgressing his vow and rule, or forsaking his obedience, but only with the intention of fleeing the malice of his ministers, of his order and of the inquisitor at Marseilles. ${ }^{54}$

Around the year 1300, the fugitive friar Mathieu de Bouzigues explained that he fled to Italy because of the: 'rabiosa malicia e dessenament dels mieus cruzels adversaris, que me mordon e me roson en las preondesas de las mias ventralhas, diffamans me coma heretge', (the rabid malice and ignorance of my cruel adversaries, who bite and gnaw in the depths of my bowels, defaming me by calling me a heretic). ${ }^{55}$ Raimon de Cornet makes a similar point by stating to the Minister General that the greatest enemies of the Friars Minor are their own confrères.

The partimen with Pey Trencavel d'Albi (A XXIX) also treads a fine line between fact and literary fiction. Pey (Peyre) Trencavel might be identified as the heresiarch who was

\footnotetext{
${ }^{53}$ Perugi, Trovatori a Valchiusa, p. 128.

${ }^{54}$ Burr, ‘Raymond Déjean’, p. 76.

${ }^{55}$ Jean Duvernoy, 'Les Spirituels et les Jeux floraux', lecture given at the Académie des Jeux Floraux, Toulouse, < http://jeuxfloraux.fr/67.html > [checked 10 April 2013], F. Delorme, 'La Confessio Fidei du Frère Mathieu de Bouzigues,' Études Franciscaines 49 (1937): 224-39, p. 233.
} 
captured and transferred to the inquisitorial tribunal of Carcassonne in 1327 after over a decade as a fugitive. Noulet and Chabaneau thought that it was likely, save that the Spiritual friar was from the diocese of Béziers and not Albi. ${ }^{56}$ Recently, Burnham has uncovered evidence that Peyre Trencavel of Béziers escaped from Carcassonne to Italy. ${ }^{57}$ Raimon opens the debate poem and invites Trencavel to choose if he would prefer to live as a fool among the wise, or a wise man among fools (ll. 3-4). Trencavel chooses folly because he trusts that the wise will give him clothing, food and drink, and will be content to laugh at him affectionately (ll. 9-12). He speculates that Raimon will endeavour to live as a wise man among fools, and be rewarded with hunger and cold. Raimon replies that, on the contrary, the wise will take fright and imprison Trencavel in a tower where he will die of grief (ll. 17-24), whereas Raimon will trick the fools into letting him become their master. Trencavel advises Raimon to live among fools in order to endure the equivalent of Christ’s Passion; Raimon retorts that it is treacherous to wish that fate upon him. Trencavel asserts:

Mas de mi fol tug seran gardador,

Si conoysho nom sabcha governar,

E daran me per Dieu o per paor,

O per amor, car m’auran per joglar. (ll. 45-8)

[But all the fools shall be my guardians, I know they will not know how to govern me, and they will give me [things] for the love of God, or through fear, or out of love, because they shall have me as their minstrel.]

Raimon retorts a bad poet such as he should give up, 'que fals parlatz e captenetz error' (because you speak falsely and teach errors) (1. 51). A rubric notes that the named adjudicator

\footnotetext{
${ }^{56}$ Deux manuscrits, p. xix.

${ }^{57}$ Burnham, So Great a Light, pp. 171-5; ‘A Prosopography’, item 252.
} 
Arnaut Daunis (or d'Aunis) never judged the poem. Pey Trencavel gives an eloquent picture of living in secret off the charity, fear or love of others. It is Raimon who boasts that he can dominate the fools by posing as one of their number, 'Car per mo sen los sabray contraffar' (l. 24) ('because with my good sense I will be able to copy them').

\section{Conclusion}

Historians who study inquisition depositions warn their readers that 'what we can learn ultimately depends on what the inquisitors wanted to know and what the defendants were willing to tell them' ${ }^{58}$ A similar note of caution must be sounded regarding the poems in the Registre de Cornet. It should come as no surprise to find a former Franciscan so deeply involved in the composition and development of secular forms of lyric poetry, one of the 'minstrels of the Lord' ${ }^{59}$ The sinful priest who narrates the Truffa, the tavern-seeking capela salvatge of the partimen and the courtly chaplain are all facets of a literary persona, as Marina Navàs has suggested. ${ }^{60}$ Raimon’s father, also called Raimon de Cornet, composed a crusade poem for Count Henry II of Rodez, in which he criticised the posthumous trial on suspicion of heresy of Pope Boniface VIII (A XXXIX). ${ }^{61}$ The county of Rodez was absorbed by the counts of Armagnac in the early fourteenth century, so it is plausible that Raimon's patrons reflect a family tradition. Raimon's works can be viewed as evidence of the survival of a tradition of poetic debates about topical religious controversies that was designed for a relatively limited audience.

This being said, Raimon's poems assume a great deal of knowledge about the tribulations of a fugitive Spiritual Franciscan. The texts echo statements that are made in the

\footnotetext{
${ }^{58}$ Burr, 'Raymond', p. 76.

${ }^{59}$ Loewen, pp. 253-9.

${ }^{60}$ Navàs, op. cit. (see also Navàs’s forthcoming doctoral thesis on Raimon de Cornet).

${ }^{61}$ Perugi, Trovatori a Valchiusa, pp. 161-9.
} 
inquisition depositions, some of them surely the result of coercion by the learned clerics who wanted to provide the evidence they needed to be able to identify 'heresiarchs' and their supporters. The sentences passed on the Spiritual friars accused them primarily of disobedience to papal authority through their belief in the infallibility of the Franciscan rule and their rejection of papal authority. They were only secondarily accused of defending Olivi’s alleged apocalyptic doctrines, viewing the Church as the Great Whore of Babylon, persecuting the friars: beliefs that were described as heretical, 'insane' and 'fabulous'. Accordingly, Raimon seems to be more interested in poverty than in eschatology. ${ }^{62}$ If we treat the poems as reliable documents, they imply that Spirituals did not indulge in the inflammatory rhetoric that was ascribed to them by their hostile prosecutors. However, if we read them as texts that were produced with an eye to a secular audience that could not be trusted, we are back in a hall of mirrors, reading poems that depict the Spirituals as their less ardent enemies wished to see them: rebellious, disobedient, 'subtle', but living chastened if melodious lives as fools among the wise.

\footnotetext{
${ }^{62}$ Given, 'The Béguins', pp. 148, 156-9. However, see Passerat's discussion of A XXVI in 'Les Outrances verbales', pp. 153-4.
} 